\title{
PARASITIC NEMATODES FROM TONKIN, INDO-CHINA, INCLUDING A NEW SPECIES OF ASCARIDIA
}

\section{By Benjamin Schwartz}

Of the Zoological Division, Bureau of Animal Industry, United States Department of Agriculture

The following report is based on a small collection of nematodes, largely from domestic animals, received from Maj. E. Houdemer, Chief of the Clinic at the École Vétérinaire at Hanoi (Tonkin) Indo-China. In addition to a new species of Ascaridia from the goose which is described in this paper, there were found a species of Rictularia from a rat which is probably a new species, and specimens of the genus Porrocaecum from a heron (genus and species unknown) which require further study.

\section{Superfamily OXYUROIDEA}

\section{Family OXYURIDAE}

\section{Genus OXYURIS Rudolphi, 1803}

OXYURIS EQUI (Schrank, 1788)

\section{Host.-Equus caballus.}

Location.--Unknown.

Only short-tailed forms were found, but Major Houdemer states that long-tailed forms also occur in horses in Tonkin.

\section{Superfamily ASCAROIDEA}

\author{
Family ASCARIDAE \\ Genus ASCARIS Linnaeus, 1758 \\ ASCARIS LUMBRICOIDES Linnaeus, 1758
}

Host.-Homo sapiens.

The specimens which are sexually immature were vomited by a breast fed infant (native) only two months old.

No. 2538.-Proceedings U. S. National Museum, Vol. 66, Art. I. 


\section{Genus BELASCARIS Leiper, 1907}

BELASCARIS CATI (Schrank, 1788)

Host.-Panther (Felis, species).

Location.-Intestine.

\section{Genus PORROCAECUM Railliet and Henry, 1912}

Host.- "Crabier," a species of heron.

Location.-Esophagus, stomach, intestine.

More than one species of Porrocaecum is present in the lot.

\section{Family HETERAKIDAE}

\section{Genus HETERAKIS Dujardin, 1845}

HETERAKIS BERAMPORIA Lane, 1914

Host.-Gallus domesticus.

Location.-Cecum.

This species was described from the cecum of the domestic fowl at Berhampore, Bengal, India. It was also found by the present writer to be a common parasite of chickens in the Philippine Islands, often living in association with a related species (Heterakis gallinae $=H$. papillosa) from which it may be differentiated by its smaller size and by the fact that its spicules are considerably shorter and nearly equal in length.

The present writer also found that the larvae of this parasite occur in nodules that are located in the wall of the cecum, principally in the submucosa.

It may be noted in this connection that Travassos (1920) includes the Heterakidae, from which he excludes the genus Ascaridia, with the Oxyuroidea, largely on the basis of the esophageal bulb.

\section{Genus ASCARIDIA Dujardin, 1845}

ASCARIDIA LINEATA (Schneider, 1866)

\section{Hosts.-Gallus domesticus, Anser domesticus.}

Location.-Intestine.

This species was described from Brazil from the intestine of Gallus domesticus. Von Linstow (1883) records this species from the same host in Turkestan. Travassos (1913) describes Ascaris lineata from the common fowl in Brazil, the type locality of this species, and records the length of the spicules as $1.4 \mathrm{~mm}$. This species has also been recorded from the Belgian Congo and from Europe. Recently Boulenger (1923) records this species from Zanzibar, having found a single specimen (male) in the stomach of the domestic fowl. Boulenger calls attention to the fact that the figures of different authors do not agree in all details as 
regards the shape and direction of certain papillae in the male and ascribes these differences to individual variation. Thus, Schneider (1866) figures the most cephalad papilla rounded in shape, whereas Von Linstow, Boulenger, and Travassos figure it as being transversely elongated. With regard to the direction of the second lateral papilla there is also a diversity of views, since Schneider and Boulenger figure it as being directed ventrally, whereas Von Linstow and Travassos figure it as being directed laterally. Boulenger also regards Ascaridia hamia Lane, 1914, a synonym of Ascaridia lineata, and the present writer concurs in this opinion. Lane's figure shows the second lateral papilla directed laterally and his drawing of the most cephalad papilla agrees with that of Schneider.

Specimens examined by the present writer show considerable variation as regards the shape and direction of certain papillae as well as regards the size of the spicules. In immature specimens from the goose the spicules are from 530u to 570u long, the second lateral papilla being directed ventrally in some specimens, and having a lateral direction in others. In larger, though still immature specimens, from the chicken, the spicules are from $700 \mu$ to $800 \mu$ long, and the second lateral papilla is directed laterally. The first ventral papilla is transversely flattened in most speeimens examined by the present writer, although in one immature specimen it was found to be rounded, agreeing in shape with this papilla as figured by Schneider and Lane. Sexually mature specimens of Ascaridia lineata from the chicken agree in practically all respects with the description of Ascaridia hamia Lane, which is also based on mature specimens. In my specimens the spicules are up to $2.4 \mathrm{~mm}$. in length whereas Lane gives the length of the spicules as $2 \mathrm{~mm}$. The sucker is $0.2 \mathrm{~mm}$. in diameter, according to Lane, this measurement agreeing with that of Boulenger, so far as can be judged from the latter's figures. In specimens examined by the writer the sucker showed considerable variation, being only $0.15 \mathrm{~mm}$. in diameter in immature specimens and attaining a diameter of $0.25 \mathrm{~mm}$. in large sexually mature forms.

The females also show considerable variation as regards the length of the tail (from $0.5 \mathrm{~mm}$. to $1.5 \mathrm{~mm}$. depending upon the size of the specimens) and as regards the length of that portion of the vagina that extends cephalad (from $0.425 \mathrm{~mm}$. to $1 \mathrm{~mm}$.), the shortest distance corresponding to the youngest forms and the longest distance to the largest forms. Similar variations were found as regards the distance of the excretory pore and nerve ring from the cephalic extremity the length of the tail in the male, and in other characters.

In this connection it may be noted that according to Travassos (1920) the genus Ascaridia belongs to the family Ascaridae and is placed in a distinct subfamily (Ascaridinae) on the basis of the 
structure of the esophagus which is without a bulb. The fact that the members of this genus have a pre-anal sucker and a bursa-like tail in the male has been generally considered sufficient ground to warrant their inclusion in the Heterakidae, and this classification is followed by most helminthologists.

ASCARIDIA ANSERIS, new species

Male.-32 mm. long by $600 \mu$ wide. Cuticle finely striated. Head,

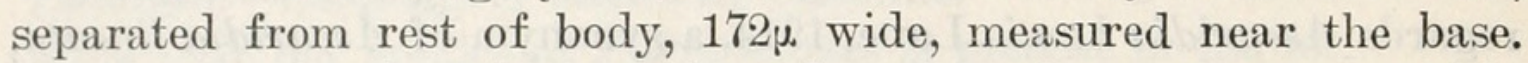
Esophagus simple, $1.75 \mathrm{~mm}$. long by $285 \mu$ in maximum width. Nerve ring about $350 \mu$ from cephalic extremity. Sucker circular, $138 \mu$ by $130 \mu$, its posterior margin being located at a distance of $172 \mu$. from the anus and at about 700u. from the posterior extermity. On one side of the body there are 14 papillae of which 5 are pre-anal and 9 post-anal (fig. 1). The first three papillae are ventral in position and are arranged in a row on each side of the sucker the most cephalad papilla being anterior to the sucker, the middle one lying in the region of sucker and the last papilla being posterior to the sucker. Of the next two papillae, one is ventral and one is lateral (1l). In the following group of three papillae one is lateral (2l) and two appear to have a ventral position. Of the remaining 6 papillae four are lateral $(3 l, 4 l, 5 l, 6 l)$ and two ventral. The distances between the tips of the first four lateral papillae are almost equal and greater than the distance between the last two lateral papillae.

The papillae on the other side of the worm are only 13 in number, the corresponding first lateral papilla being absent. The remaining papillae, though corresponding in number to those on the opposite side, show in some respects a different arrangement; the third lateral papilla appears to be absent, being replaced by a ventral papilla $(x)$. The fourth, fifth, and sixth lateral papillae correspond to those on the opposite side.

The spicules nearly equal, $820 \mu$ and $827 \mu$ long, respectively, and terminate bluntly. The tip of the tail in my specimen is broken off, as can be seen from the jagged posterior extremity in the illustration.

Female.-Unknown.

Host.-Anser domesticus.

Location.-Small intestine.

Locality.-Hanoi (Tonkin) Indo-China.

Type specimen.-U. S. National Museum Helminthological Collections No. 26011.

Variation in number and in position of papillae in the genus Ascaridia is apparently not uncommon. In Ascaridia columbae, as recently figured by Baylis and Daubney (1922), the papillae show considerable variation in position. It is not improbable that the 
asymetrical arrangement of the papillae in the specimen of $A$. anseris is an abnormality.

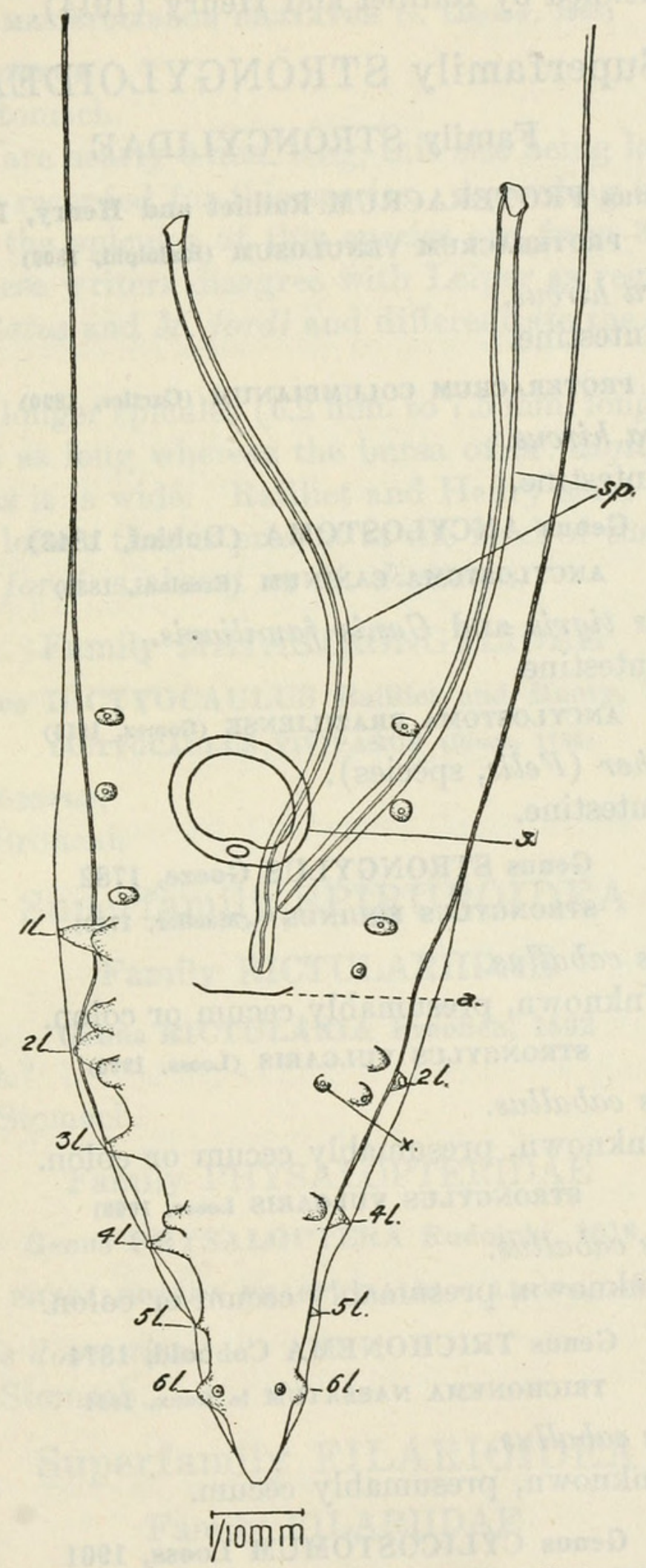

Fig. 1.-Ascaridia Anseris (Tail of Male) : $a$, Anus ; $s$, Sucker ; $s p$., Spicules ; $1 l-6 l$, First to Sixth lateral Papillae, Respectively ; $x$, Accessory Ventral Papilla

Lane $(1914,1917)$ has limited the definition of the genus Ascaridia to species having 10 pairs of papillae in the male. If Lane's suggestion were followed it would be necessary to create new genera presumably on the basis of the number of papillae in the male, as 
these differ in number in certain species. For the present, at least, it seems more advisable to adhere to the conception of the genus Ascaridia as defined by Railliet and Henry (1914).

\section{Superfamily STRONGYLOIDEA}

Family STRONGYLIDAE

\section{Genus PROTERACRUM Railliet and Henry, 1913}

PROTERACRUM VENULOSUM (Rudolphi, 1809)

Host.-Capra hircus.

Location.-Intestine.

PROTERACRUM COLUMBIANUM (Curtice, 1890)

Host.-Capra hircus.

Location.-Intestine.

Genus ANCYLOSTOMA (Dubini, 1843)

ANCYLOSTOMA CANINUM (Ercolani, 1859)

Hosts.-Felis tigris and Canis familiaris.

Location.-Intestine.

ANCYLOSTOMA BRAZILIENSE (Gomez, 1910)

Host.-Panther (Felis, species).

Location.-Intestine.

\section{Genus STRONGYLUS Goeze, 1782}

STRONGYLUS EQUINUS ${ }^{1}$ (Mueller, 1780)

Host.-Equus caballus.

Location.-Unknown, presumably cecum or colon.

STRONGYLUS VULGARIS (Looss, 1900)

Host.-Equus caballus.

Location.-Unknown, presumably cecum or colon.

STRONGYLUS VULGARIS Looss, 1900)

Host.-Equus caballus.

Location.-Unknown, presumably cecum or colon.

Genus TRICHONEMA Cobbold, 1874

TRICHONEMA NASSATUM le Roux, 1924

Host.-Equus caballus.

Location.-Unknown, presumably cecum.

Genus CYlicostomum Looss, 1901

Subgenus Cylicocercus Ihle, 1922

Cylicocercus Catinatus (Looss, 1900)

Host.-Equus caballus.

Location.-Unknown, presumably cecum.

1 The five species of horse strongyles were determined by Miss E. B。 Cram of this division. 


\section{Family TRICHOSTRONGYLIDAE}

Genus MECISTOCIRRUS Railliet and Henry, 1912

MECISTOCIRRUS DIGITATUS (v. Linstow, 1906)

\section{Host.-Bos taurus.}

Location.-Stomach.

The spicules are nearly $6 \mathrm{~mm}$. long, this size being larger than has heretofore been recorded for this species. According to Railliet and Henry (1912) the spicules of this species are from $3.8 \mathrm{~mm}$. to 4.5 $\mathrm{mm}$. long. These writers disagree with Leiper as regards the identity of $M$. digitatus and $M$. fordi and differentiate the two species as follows:

$M$. fordi has longer spicules (6.2 mm. to $7.5 \mathrm{~mm}$. long); its bursa is almost as wide as long whereas the bursa of $M$. digitatus is almost twice as long as it is wide. Railliet and Henry state moreover that the projecting lobule that is present at the level of the external dorsal ray in $M$. fordi is absent in $M$. digitatus.

\section{Family METASTRONGYLIDAE}

Genus DICTYOCAULUS Railliet and Henry, 1907

DICTYOCAULUS VIVIPARUS (Bloch, 1782)

Host.-Bos taurus.

Location.-Bronchi.

\section{Superfamily SPIRUROIDEA}

Family RICTULARIIDAE

Host.-"Rat."

Genus RICTULARIA Froelich, 1802

Location.-Stomach.

\section{Family PHYSALOPTERIDAE}

Genus PHYSALOPTERA Rudolphi, 1819

PHYSALOPTERA PRAEPUTIALIS v. Linstow, 1889

Host.-Felis domestica.

Location.-Stomach.

\section{Superfamily FILARIOIDEA}

Family FILARIIDAE

\section{Genus DIROFILARIA Railliet and Henry, 1911}

DIROFILARIA IMMITIS (Leidy, 1856)

Host.-Felis tigris.

Location.-Right side of heart.

This is a new host for this parasite, which has, however, on several occasions, been reported from Felis domestica. 


\section{Genus SETARIA Viborg, 1795 \\ SETARIA EQUINA (Abildgaard, 1789)}

Host.-Equus caballus.

Location.-Unknown.

SETARIA, species

Host.-Equus caballus.

Location.-Eye.

A single immature female specimen from the eye of the horse. The posterior end is smooth, as in Setaria digitata, but there is no terminal knob. The specimen in question is probably Setaria digitata (v. Linstow, 1906). This nematode was originally described from Ceylon, and has also been recorded from India. It is possible that the terminal knob appears only in mature forms, presumably as a result of a constriction in the cuticle in the posterior region.

Heretofore young filarids from the eye of the horse have been found to be Setaria labiato-papillosa by Railliet and Henry (1911). According to Bauche and Bernard (1912) young forms of Setaria labiato-papillosa occur in the eye of the horse in Anam.

\section{Family THELAZIIDAE}

\section{Genus CHEILOSPIRURA Diesing, 1861}

CHEILOSPIRURA HAMULOSA (Diesing, 1851)

Host.-Gallus domesticus.

Location.-Gizzard.

Several female specimens were found under the horny lining of the gizzard, firmly attached to the inner surface of the lining.

\section{REFERENCES TO LITERATURE CITED}

Bauche, J.; and Bernard P. Noel.

1912. Note sur quelques filaires animales de l' Anam central. Bull. de la Société de Path. Exotique, vol. 5 (no. 8), pp. 622-624.

Baylis, H. A. ; and Daubney, R.

1922. Report on the parasitic nematodes in the collection of the Zoological

Survey of India. Mem. Indian Mus., Calcutta, vol. 7 (no. 4), pp. 263-347, figs. $1-75$.

Boulenger, C. L.

1923. A collection of nematode parasites from Zanzibar. Parasitol., Cambridge [Eng.], vol. 15 (no. 2), pp. 113-121, figs. 1-5.

Lane, Clayton.

1914. Suckered roundworms from India and Ceylon. Indian Med. Journ., vol. 2 (no. 2 ), pp. 655,669 , pls. $74-81$.

1917. Gireterakis girardi (n. g., n. sp.) and other suckered nematodes. Indian Journ. Med. Research, vol. 4 (no. 4), pp. 754-765, pls. 43-48, figs. 1-30. 
v. Linstow, $\mathrm{O}$.

1883. Nematoden, Trematoden und Acanthocephalen, gesammelt von Prof. Fedtschenko in Turkestan. Arch. f. Naturg., 49. Jahre., vol. 1 (no. 2), pp. 274-314, pls. 6-9, figs. 1-52.

Railliet, A. ; and Henry, A.

1911. Sur une filaire péritoneale des porcins. Bulletin de la Société de Path. Exotique, vol. 4 (no. 6), pp. 387-389.

1912. Observations sur les Strongylidés du genre Nematodirus. Bull. Soc. path. exot., vol. 5 (no. 1), pp. 35-39.

1914. Essai de classification des "Heterakidae." [Compt.-rend.] 9. Cong. internat. de zool., Monaco, pp. 674-682.

SchNeIDER, ANTON

1866a. Monographie der Nematoden. viii +357 pp., 122 figs., 28 pls., 343 figs.

Travassos, Lauro.

1913. Sobre as especies brazileiras da subfamilia Heterakinae Railliet and Henry. Mem. Inst. Oswaldo Cruz, vol. 5 (no. 3), pp. 271-318, pls. 27-31, figs. 1-38.

1920. Esboço uma chave de geral dos nematodes parasitos. Rev. de vet. et zootech., vol. 10 (no. 2), pp. 50-70, 1 chart. 


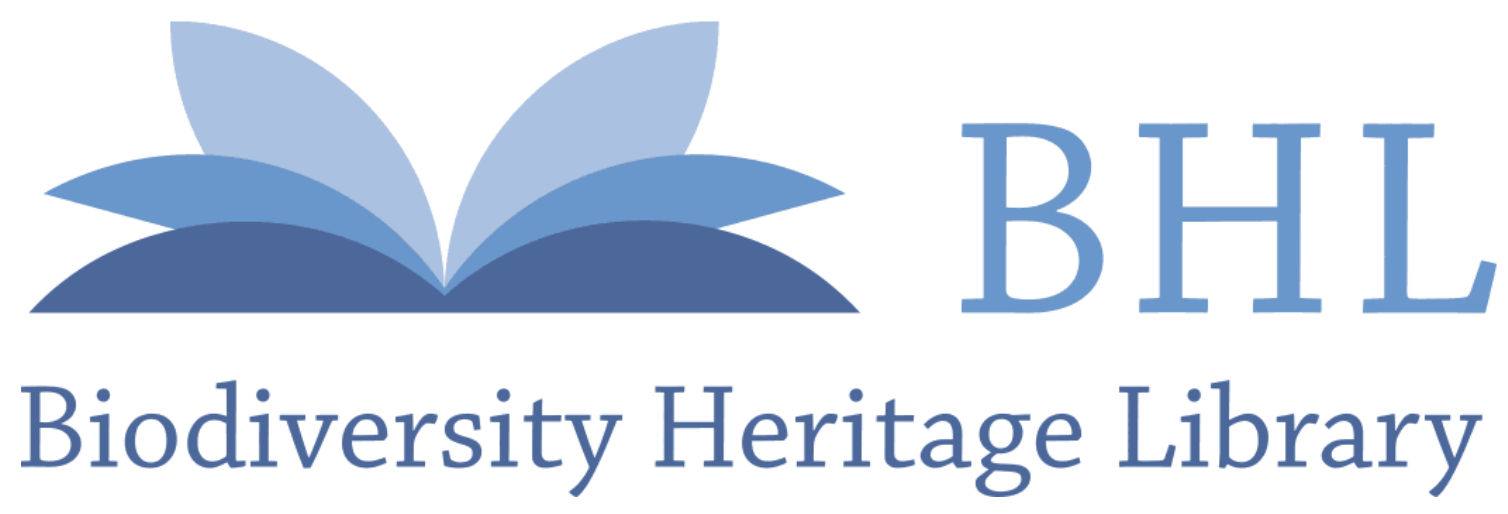

Schwartz, Benjamin. 1925. "Parasitic nematodes from Tonkin, Indo-China, including a new species of Ascaridia." Proceedings of the United States National Museum 66(2538), 1-9. https://doi.org/10.5479/si.00963801.66-2538.1.

View This Item Online: https://www.biodiversitylibrary.org/item/32809

DOI: https://doi.org/10.5479/si.00963801.66-2538.1

Permalink: https://www.biodiversitylibrary.org/partpdf/9072

\section{Holding Institution}

Smithsonian Libraries

\section{Sponsored by}

Smithsonian

\section{Copyright \& Reuse}

Copyright Status: NOT_IN_COPYRIGHT

Rights: https://www.biodiversitylibrary.org/permissions/

This document was created from content at the Biodiversity Heritage Library, the world's largest open access digital library for biodiversity literature and archives. Visit BHL at https://www.biodiversitylibrary.org. 